Section Editor

Mitchell S.V. Elkind, MD, MS

Julian Maroski, MD Juri Katchanov, MD Gordian Branding, MD Frank Hamilton, MD

Correspondence to

Dr. Katchanov:

juri.katchanov@charite.de
Download teaching slides: www.neurology.org.

\title{
Teaching NeuroImages: \\ Conus medullaris involvement in cerebrospinal toxoplasmosis
}

Figure Conus medullaris toxoplasmosis in advanced HIV
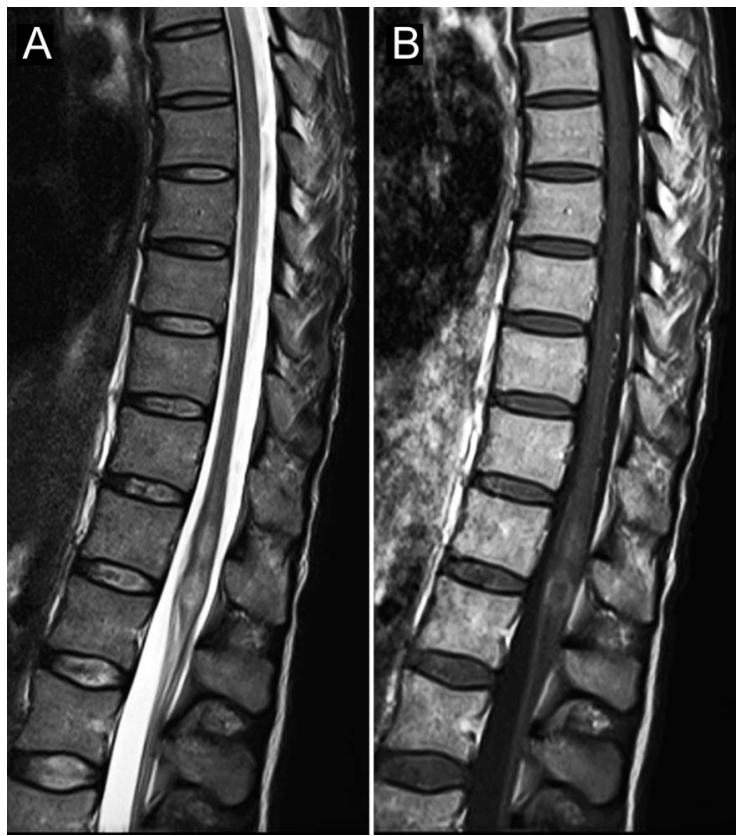

T2-weighted images show 2 round hyperintensities involving the conus medullaris $(A)$ with ring enhancement on contrast T1 images (B).

A 41-year-old woman originally from West Africa presented with a 3-week history of generalized weakness. Clinical examination demonstrated quadriparesis, urinary incontinence, and reduced level of consciousness. The imaging of the neuraxis revealed multiple bilateral cerebral lesions, including basal ganglia and midbrain. Spinal cord imaging showed lesions in the conus medullaris (figure). The HIV test was reactive, with a CD4 count of 10 cells $/ \mu \mathrm{L}$ (normal range $700-1,200 / \mu \mathrm{L}$ ). CSF PCR for Toxoplasma gondii was positive. CSF cryptococcal antigen, fungal and mycobacterial cultures, Epstein-Barr virus PCR, and Mycobacterium tuberculosis PCR were negative.

Conus medullaris involvement is an uncommon manifestation of toxoplasmosis in advanced HIV. ${ }^{1,2}$

\section{AUTHOR CONTRIBUTIONS}

Julian Maroski: drafting/revising the manuscript, study concept or design, analysis or interpretation of data, accepts responsibility for conduct of research and final approval, contribution of vital reagents/tools/patients.
Juri Katchanov: drafting/revising the manuscript, analysis or interpretation of data, accepts responsibility for conduct of research and final approval, acquisition of data. Gordian Branding: drafting/revising the manuscript, analysis or interpretation of data, accepts responsibility for conduct of research and final approval, acquisition of data. Frank Hamilton: analysis or interpretation of data, accepts responsibility for conduct of research and final approval, acquisition of data, study supervision.

\section{STUDY FUNDING}

No targeted funding reported.

\section{DISCLSOURE}

The authors report no disclosures relevant to the manuscript. Go to Neurology.org for full disclosures.

\section{REFERENCES}

1. Vyas R, Ebright JR. Toxoplasmosis of the spinal cord in a patient with AIDS: case report and review. Clin Infect Dis 1996;23:1061-1065.

2. Overhage JM, Greist A, Brown DR. Conus medullaris syndrome resulting from Toxoplasma gondii infection in a patient with the acquired immunodeficiency syndrome. Am J Med 1990;89:814-815.

From the Departments of Neurology (J.M., F.H.), Infectious Diseases and Gastroenterology (J.K.), and Radiology (G.B.), Auguste-Viktoria-

Klinikum, Berlin, Germany. 


\section{Neurology}

\section{Teaching NeuroImages: Conus medullaris involvement in cerebrospinal toxoplasmosis}

Julian Maroski, Juri Katchanov, Gordian Branding, et al. Neurology 2013;81;e165

DOI 10.1212/01.wnl.0000436616.58705.12

This information is current as of November 25, 2013

\section{Updated Information \& Services \\ Supplementary Material \\ References \\ Subspecialty Collections}

Permissions \& Licensing

Reprints including high resolution figures, can be found at: http://n.neurology.org/content/81/22/e165.full

Supplementary material can be found at: http://n.neurology.org/content/suppl/2013/11/22/81.22.e165.DC1

This article cites 2 articles, 0 of which you can access for free at: http://n.neurology.org/content/81/22/e165.full\#ref-list-1

This article, along with others on similar topics, appears in the following collection(s):

\section{All Infections}

http://n.neurology.org/cgi/collection/all_infections

Parasitic infections

http://n.neurology.org/cgi/collection/parasitic_infections

Spinal cord infarction

http://n.neurology.org/cgi/collection/spinal_cord_infarction

Information about reproducing this article in parts (figures,tables) or in its entirety can be found online at:

http://www.neurology.org/about/about_the_journal\#permissions

Information about ordering reprints can be found online:

http://n.neurology.org/subscribers/advertise

Neurology ${ }^{\circledR}$ is the official journal of the American Academy of Neurology. Published continuously since 1951, it is now a weekly with 48 issues per year. Copyright (C 2013 American Academy of Neurology. All rights reserved. Print ISSN: 0028-3878. Online ISSN: 1526-632X.

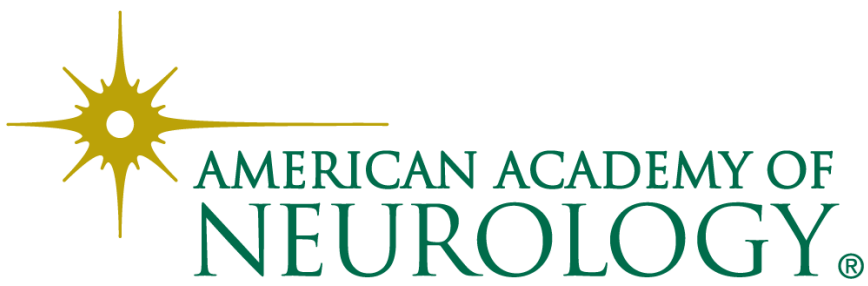

